\title{
BLENDING THE PRINCIPLES OF SUGGESTOPEDIA AND THE THEORY OF SPEECH ACTS IN WRITING SUGGESTOPEDIC DIDACTIC TEXTS, WITH REFERENCE TO GERMAN AND ZULU SCRIPTS
}

RH. Bodenstein

This paper suggests that language teachers who use the suggestopedic method should write their own texts that comply with suggestopedic principles. This is imperative because of the lack of material that can be acquired and used in such courses. Writing their own scripts also enables teachers to identify with their materials and brings much reward and personal growth.

Guidelines for the writing and setting up of these texts are provided. The text should embody the philosophic and didactic framework of suggestopedia. It should also be presented as a didactic play wherein the language components to be learned are presented in the form of new scenes in a continuous drama text. Traditional beliefs about level of complexity of the language suitable for beginners' courses are considered unfounded. Suggestopedic scripts therefore contain complex, 'real life' language from the outset, starting with the language needed to make contact with native target language speakers.

The main guideline for the organisation and structuring of the text is that it should mirror authentic communicative situations. The paper therefore argues that suggestopedic scripts should be written according to the lists of language functions (or speech acts) and topic areas required for the so-called 'threshold level' of language competence.

The paper concludes with examples from a German and a Zulu text to illustrate the didactic and structural principles and guidelines that were outlined in the article.

Die artikel voer aan dat taalonderwysers wat die suggestopediese metode gebruik, self tekste behoort te skryf wat strook met die suggestopediese beginsels. Die gebrek aan geskikte materiaal op die mark noodsaak hulle om dit te doen. Wanneer onderwysers hulle eie tekste skryf, beteken dit egter ook dat hulle met die onderrigmateriaal kan identifiseer. Dit kan professioneel lonend wees en persoonlike groei teweeg bring.

Riglyne vir die skryf en ontwerp van sulke tekste word verskaf. Die teks behoort in die filosofiese en didaktiese raamwerk van suggestopedia in te pas. Dit behoort as 'n didaktiese toneelstuk 
aangebied te word; die taal-eksponente wat aangeleer moet word, word telkens via nuwe tonele van 'n deurlopende dramateks voorgestel. Tradisionele aannames oor die vlak van kompleksiteit van die taal wat vir beginnerskursusse geskik is, word as ongeldig beskou. Suggestopediese tekste bevat dus van die begin af komplekse taal soos dit in die werklike lewe gebruik word, beginnende by die taal wat benodig word om met moedertaalsprekers in die teikentaal kontak te maak.

Die belangrikste riglyn vir die organisasie en die strukturering van die teks is dat dit outentieke kommunikatiewe situasies moet weerspieël. Die artikel stel dus voor dat suggestopediese tekste geskryf word ooreenkomstig die lyste van spreekhandelinge en onderwerpe wat vir die sogenaamde 'drumpelvlak' van taalvaardigheid geïdentifiseer is.

Ter afsluiting van die artikel word die voorgestelde didaktiese en strukturele beginsels en riglyne aan die hand van' $n$ Duitse en 'n Zoeloe teks nader toegelig.

\section{INTRODUCTION}

Although the paper concentrates on foreign language teaching based on the suggestopedic approach, much of what is said has applications for communicative language teaching in general. As such the paper may be read as an appeal to all language teachers to improve their awareness of the multi-faceted function of didactic texts in language teaching, and as an encouragement to foreign language teachers using approaches other than suggestopedia to consider some of the ways they could gain from creating their own material.

\section{PART ONE: Reasons for writing original suggestopedic texts}

\subsection{The limited offer of ready-made suggestopedic language courses available}

The first reason why teachers using the suggestopedic approach should consider writing their own didactic scripts, is the scarcity of suitable courseware. Apart from a number of commercial language courses, most of them for self-study, hardly any suggestopedic courseware is ready to be bought and implemented. As a result, teachers who claim to be implementing suggestopedia may in fact be indiscriminatingly using materials developed for other teaching methods, naively believing that they can teach "suggestopedically" by simply adapting their style of presentation, without giving much thought to the material. Such (unsuitable) courseware could, for example, consist of random collections of conventional teaching notes and textbook texts, modified (sometimes ever so slightly) so as to fit into some vaguely identifiable suggestopedic framework. Clearly, such compilations are a far cry from proper suggestopedic material, particularly from the didactic text, which requires a standardized format and very specific components in order to serve its function in the suggestopedic cycle (cf. Dhority, 1984:8/1-4). 


\subsection{Teachers' difficulty in identifying fully with materials other than their own}

The second reason why writing original didactic scripts is advocated, has to do with the congruency of the learning environment (cf. Botha, 1990:46). In order to establish and maintain their integrity, it is necessary for teachers to identify, emotionally as well as intellectually, with what they are doing: they should be convinced of the merit of the method as well as the material they are implementing.

In the case of the suggestopedic script, this is consideration is vital. The script is the very basis of the suggestopedic cycle, and Dhority stresses the critical importance of teachers believing in its "potential effectiveness" (1984:9/3). Yet, as Friedrich points out, little attention is generally paid to it. Research on suggestopedia concentrates almost exclusively on the process of teaching, while the content is largely ignored (1994:79). Richards and Rodgers suggest that, in spite of what the founder of suggestopedia, Lozanov, proclaims in his theoretical writing, he himself offers language courses that fall short of his principles inasmuch as "the linguistic nature" of the material he uses seems "largely irrelevant" (1986:144).

A similar conclusion was arrived at by Kussler and Bodenstein. In a study conducted in 1985, they found that a number of the suggestopedic texts they investigated were "based on concepts of language, grammar and language didactics which we regard as rather old-fashioned" (1985:12). Scenes of the scripts were, for example, written to illustrate specific grammatical phenomena or to practice very specific, isolated and glaringly obvious situations with equally obvious didactic intent (e.g. "shopping for groceries in country $\mathrm{x}$ "). Krag also touches on the problem of excessive didactisation by observing that many suggestopedic textbooks ("Lehrbücher") are too boring and humourless to be inspirational (1989:175). Finally, Blair points out that the simulation of language commonly used in language courses hardly resembles adult conversational speech (1985:12). The lack of authenticity which he detects in the language of "contrived model dialogues", is prevalent in many suggestopedic scripts as well.

Texts written according to outdated concepts such as these, contradict the suggestopedic principles of wholeness and quality (cf. Kussler and Bodenstein, 1985:13). Clearly, it would be difficult for the discerning teacher to identify with them, and instead of using such materials of inferior quality, teachers should rather consider writing original texts themselves.

\subsection{The personal growth and pleasure to be had in writing original texts}

The third reason why suggestopedic teachers should consider writing their own texts, pertains to personal growth and professional gratification. Writing original didactic scripts will, in most cases, enable teachers to discover deeper dimensions of their own teaching abilities and creativity, and could lead to a considerable boost to their self-confidence. It can be quite a surprise and certainly great fun to discover the "scriptwriter" latent inside oneself. 
This paper, therefore, is an attempt to encourage teachers to write their own texts. The Zulu and German scripts referred to in part three, are examples of authors' first attempts at didactic sript writing. In both cases the authors found that the overwhelming task of writing original texts could be broken down into manageable sections by following the strategies and guidelines proposed in this paper. In fact, the process of writing became tremendously exciting and rewarding, and both texts have been used with great success, the German script at the University of Stellenbosch (for beginners' German), and the Zulu text at the South African Airways' training division (for a language and cultural appreciation course).

\section{PART TWO: Guidelines for writing suggestopedic texts}

In the following section, simple guidelines for writing suggestopedic texts will be provided.

The guidelines are grouped according to two principles:

First, we shall examine what elements the learning script should contain in order to comply with the main principles of the suggestopedic approach.

Second, we shall consider linguistic and didactic strategies for organizing and structuring the suggestopedic text.

\subsection{Suggestopedic principles to be remembered while writing scripts}

The following elements constitute the philosophic framework for suggestopedic texts and should put one into the proper mind-set to commence writing (cf. Kussler and Bodenstein, 1985:13):

2.1.1 The text should contribute to the general atmosphere of relaxation, happiness and lack of anxiety in class.

2.1.2 The text should help the teacher establish and maintain authority and double-plane congruency.

2.1.3 The text should facilitate the students' growth of self-esteem and realization of their own potential.

Botha (1990) adds more criteria of a philosophical nature:

2.1.4 Referring to research done on the working of the human brain, he stresses that all senses should be addressed in the text. "If the text stimulates sensory perception, it ensures superior processing of the material and storage in the long-term memory" (Botha, 1990:68). 
2.1.5 Similarly, "metaphors, parables, fables and vivid imaging involving all the senses" should be included to enrich the suggestopedic text and to stimulate the so-called "right hemisphere" of the brain; moreover, "positive suggestions could be assimilated and internalized through these elements" (Botha 1990:68).

These principles should generally "be incorporated into the text in a holistic sense: they should feature as internal elements of the text; they should constitute and determine its plot, its message and its style" (Kussler and Bodenstein, 1985:13).

\subsection{The format of the suggestopedic text}

The suggestopedic text is presented in class as a didactic play, the plot of which unfolds scene after scene during the rendering of the text as suggestopedic concerts (Botha 1990: 54-56).

The exact number of scenes in a suggestopedic script is not fixed, although some writers suggest hat there is a standardised model. Dryden and Vos, for example, suggest that "linguists agree hat 90 percent of all speech uses only about 2,000 words" and that "an accelerated learning anguage course therefore builds the basic 2,000 words into, say, 12 different "plays" or scenes ike a 12-act drama" (1996:173). Attempts to quantify the goals and aims of courses in such implistic terms cannot be taken too seriously. Vielau (1988) suggests that the statistics used to orove the effectiveness of teaching methods are, in many cases, nonsensical. Very often the quantifiable components of a course, e.g. the number of contact hours or the volume of rocabulary learned, offer very little reliable evidence about the intrinsic value of the course in question (cf. Vielau 1988:18). Even some of Lozanov's own reports, in which he claims to be ising empirical data and scientifically valid statistics to prove the success of his method, have een severely criticised for their lack of precision (cf. Scovel 1979, Mans 1981). The number of inits (e.g. words) learned in a course and the exact length of the suggestopedic script are clearly o reliable indications of the communicative competence such a course can mediate. However, he mere fact that a continuous drama text is used in suggestopedic courses instead of the short icenes prevalent in most conventional courses for beginners, is significant, as will be shown inder 2.3 .

resenting new materials in the form of new scenes of a continuous drama text (hitherto unseen y the students), creates curiosity and a sense of anticipation and surprise (cf. Dhority, 1984:8/2). The script should captivate the attention of the audience (in this case the learners) in a manner imilar to that of a popular soap opera holding television viewers spellbound from episode to pisode.

$\mathrm{n}$ order to create the feeling of anticipation and an eagerness in learners to find out what happens ext in each subsequent scene, the script should include the following elements:

.2.1 A steady narrative line; 


\subsection{2 a fair amount of dramatic action; and}

2.2.3 a positive emotional (possibly romantic) relationship between the characters (cf. Kussler and Bodenstein 1985:15).

\subsection{The level of "difficulty" of the script}

From the point of view of foreign language didactics, one of the main advantages of the suggestopedic approach to foreign language learning is the fact that it does not link the beginners' linguistic limitations with "a corresponding limitation in intellectual content of the study material and presentation" (Kussler and Bodenstein, 1985:15). There is, in this respect, a significant difference between materials used in conventional language courses and the didactic script used in suggestopedic teaching.

\subsubsection{The volume of new language that can be presented per scene}

In conventional beginners' courses, relatively small and carefully sifted units of language are usually introduced per chapter, often with a bearing on a specific grammatical phenomenon. At best the language in such courses is presented in short, isolated texts, illustrating the (grammatical) phenomenon to be studied, or, at worst, in lists of vocabulary without communicative context. It is assumed that beginners will not be able to manage bigger and more complex "chunks" of information about the new language.

In contrast to this, the suggestopedic method demands that "the material for each new lesson must be given in large portions and the theme of each lesson must be complete and given globally" (Lozanov, quoted in Botha, 1990:77). The target language is not sifted to create an illusion of simplicity at all. On the contrary, the learner is, from the outset, encouraged to experience and savour the richness and complexity of the new language. It is not only assumed that the learners are able to manage such a task, but that their minds will in fact thrive on rich and complex linguistic input (cf. Botha 1990:61)

\subsubsection{The progression according to which materials are presented}

The underlying principle according to which the material in most conventional communicative courses is structured, is that of a progression from what is perceived to be grammatically "easy" to what becomes increasingly "difficult".

Specific problems arising from a structural grammatical approach per se are discussed under 2.4.1. At this point only the progression, i.e. moving from "easy" to "difficult" language, will be examined. This progression is, in many cases, an illusion. The German verb "sein" (to be), for example, is included in the first chapter of virtually every language course, although the pattern of its conjugation is the most irregular and difficult of all the German verbs. Clearly, it has to be used right from the start if one is to introduce oneself and talk about one's identity, and it can, in 
a communicative course, not simply be put aside for later. However, to suggest that it should be introduced early because it is "easy", is simply not true.

In contrast to the notion of moving from the "easy" to the "difficult", suggestopedic foreign language texts start with the language which is required to make contact with native speakers of the target language, irrespective of its "difficulty". From there the courses progress to more varied and more sophisticated levels of communicative competence. The very first scene of the script can, therefore, contain some of the most complex and difficult structures of the language, while even the very last lesson of a course does not necessarily have to be more difficult than the first (cf. Rose, 1985: 94).

It is with regard to the volume and the degree of complexity of the language presented in the script that suggestopedia has probably made its strongest impact on language teaching in general. Although it would be difficult to prove, I believe that the format of the suggestopedic text has fundamentally challenged textbook writers of language courses and led them to change the way they go about planning and writing (foreign) language courses. ${ }^{1}$ The notion of a painstakingly orderly and systematic presentation of the language to be learned, has, over the last ten years or so, been broadened in most modern language courses to include more interesting and, indeed, more entertaining materials in more authentic and global settings. One could argue that this could simply be ascribed to the fact that communicative language teaching methods have been gaining ground. I wouldn't be surprised, however, if one were to discover that the new (and unorthodox) parameters set by suggestopedic language teaching substantially contributed to this development.

\subsection{The organization and structure of the text}

As has been mentioned, the suggestopedic method demands that "the material for each new lesson must be given in large portions and the theme of each lesson must be complete and given globally" (Lozanov, quoted in Botha, 1990:77). Clearly, didactic considerations should not "interfere too strongly with the narrative and the psychological credibility of the story" (Kussler and Bodenstein, 1985:15).

On the other hand, Lozanov also stipulates that "the material must be presented in meaningful aggregates" (quoted in Botha, 1990:77). When writing a suggestopedic script, one will therefore have to use some structuring principle or some meaningful progression other than the story line to ensure that the script will not only be "entertaining and interesting to the students" (Lozanov, quoted in Botha, 1990:77) but also serve its didactic function in a foreign language course.

When Kussler and I wrote our first suggestopedic course, we considered two theoretical concepts according to which the script could be written:

\subsubsection{Structural grammatical approach}


It would be possible to plan the text according to a grammatical progression, as most foreign language courses do, starting with "easy" structures and gradually moving to more "difficult" ones (cf. 2.3.2.)

However, Krashen and Terrell (1983) and Krashen (1985) have alerted teachers to serious problems of a structural grammatical approach to language teaching. Krashen hypothesizes that conscious knowledge about the rules of a language serves a purpose only when the performer is "consciously concerned about correctness" and when he or she "knows the rule" (Krashen 1985:2). After many years of language teaching, I agree with him that both these conditions are "difficult to meet". Focusing on form may, in some (rare) cases, "result in somewhat more grammatical accuracy" but the fact that it can "seriously disrupt communication in conversational situations" (Krashen 1985:2) poses a formidable challenge to teachers teaching grammar in the context of a communicative approach.

Research based on more recent biological evidence about the way our brain processes information, is in line with Krashen and Terrell's view of the limited value of paradigms and rules in acquiring new language, and seems to suggest that the notion of a systematic (grammatical) order according to which a living language could best be learned, will have to be re-examined once again. There are strong indications that the human brain may be compared to a "rich, layered, messy, unplanned jungle ecosystem", and that it might therefore "thrive best in a jungle-like classroom that includes many sensory, cultural, and problem layers that are closely related to the real-world environment in which we live - the environment that best stimulates the neural networks that are genetically tuned to it" (Sylwester, 1996:23, referring to Edelmann's model of the brain). If one considers the fact that the main function of the text is to enable students to communicate in "real life", in the new language and a foreign environment "out there", it makes more sense to use a principle which is "closely related to the real-world environment in which we live" (Sylwester, 1996:23) and which, incidentally, seems more appropriate to Suggestopedia's aim of enabling students to get an overall understanding of the subject matter and a holistic command of the situations to be mastered.

\subsubsection{Authentic communicative situations, identified by topic areas and speech acts}

In order to ensure that the target language is taught in line with the requirements discussed above, courses should be structured according to a linguistic progression of authentic communicative situations (cf. 2.5). According to such a progression, speech acts (or language functions) are introduced as they would appear in the context of topic areas typical for the country (or the countries) in which the target language is spoken (cf. Kussler and Bodenstein, 1985:12). This concept has proved viable in our own teaching environment at the University of Stellenbosch, and it has, inter alia, been adopted by Colin Rose (1985:226), who uses it throughout the language courses distributed by "Accelerated Learning Systems". The concept is compatible and in line with the requirements stipulated by Lozanov, i.e. that the learners' attention in language learning should be directed "to the whole sentence, to its meaningful communicative aspect, to its place and role in the given situation" (Lozanov, 1982:156). In 
suggestopedic teaching, therefore, grammatical idiosyncrasies of the target language, as well as elements such as pronunciation and vocabulary, remain, to a great extent, on a second plane. They are rarely isolated as specific aspects to be dealt with in particular (laborious) ways, as in most traditional language teaching approaches. "They are also assimilated, but the well-trained teacher draws the students' attention to them only for a short time and then goes back quickly to the sense of the whole sentence and situation. A considerable part of these elements is learned along with the whole structure without any specific attention being paid to them" (Lozanov, 1982:156).

\subsection{The "threshold level" of language competence}

The European Council for Cultural Cooperation (established in 1972) offers a definition of what one would minimally need to be able to do in a foreign language at a level at which potential adult learners would wish to be able to communicate non-professionally with foreign language speakers "in everyday situations on topics of general interest" (Van Ek, 1976:2). This level has since come to be known as the "threshold level" of language competence (Van Ek, 1976:2). The Council found that learners at this level "would not only wish to be able to survive, linguistically speaking, as tourists in a foreign country, or in contact with foreign visitors in their own country, but they would also require the ability to establish and maintain social relations of however superficial a kind" (Van Ek, 1976:2).

The model used by the Council tries "to specify foreign language ability as skill rather than knowledge. It analyses what the learner will have to be able to do in the foreign language and determines only in the second place what language-forms (words, structures, etc.) the learners will have to be able to handle in order to do all that has been specified" (Van Ek, 1976:5).

The result of this endeavour is a useful index of language functions or speech acts required for the threshold level (Van Ek 1976:37-39), together with a list of possible topic areas which could authentically contextualise such language functions (Van Ek, 1976:27-34).

These two lists should constitute the starting-point for writing a suggestopedic text. They will be of great help in conducting a thorough needs analysis on the basis of what the target group will have to be able to do with (and in) the new language. With reference to these lists, it should be possible to establish :

- a general characterization of the type of language contacts to which the members of the target group will be exposed;

- the language activities they will engage in;

- the settings in which the foreign language will be used;

- the roles (social and psychological) the learners are likely to play in the new environment;

- the topics to be dealt with; and 
- what they will be expected to do with respect to these topics

(Van Ek, 1976:7).

To establish these variants, we suggest the following three steps: ${ }^{2}$

Step one: Identify the topic areas in which the target group will be required to communicate.

Step two: Identify the language functions or speech acts that will be required in such communicative situations.

Step three: Establish a hierarchy of importance in both categories (topics as well as speech acts) and plan the text according to this priority list.

\subsubsection{Step one:}

Identify the topic areas in which the target group will be required to communicate.

In most cases, the goal of beginners' language courses is "to enable learners to establish contact with foreign language communities" (Van Ek, 1976:14) at the so-called threshold level. The topics listed in the index for this level will therefore suffice in the majority of cases. On the other hand, one may want to write a specialized text for a target group with very specific needs. Even in such cases, it is important to keep in mind that the competence required by the threshold level is indispensable for normal interpersonal communication. Unless the learners are not going to be dealing with native speakers of the foreign language on a personal level at all, not even in writing, they are going to have to learn the skills identified for that level.

The topic areas in which learners should be able to function, according to the specifications for the threshold level, are the following:

2.5.1 (a) personal identification (name, nationality, age, character, etc.)

2.5.1 (b) house and home (type of accommodation, furniture, region, services, etc.)

2.5 .1 (c) life at home (family, daily routine, pets, etc.)

2.5.1 (d) education and (future) career (schooling, subjects, qualifications, etc.)

2.5.1 (e) free time, entertainment (hobbies, sports, cultural activities, media, etc.)

2.5.1 (f) travel (commuting, means of transport, holidays, foreign countries)

2.5.1 (g) relations with other people (friendship, aversion, making arrangements, public life, politics, etc.)

2.5.1 (h) health and welfare (the body, ailments, hygiene, medical services, etc.)

2.5.1 (i)

2.5.1 (j) shopping (facilities, prices, monetary units, weights and measures, etc.)

$2.5 .1(\mathrm{k})$

2.5.1(1) food and drink (types of food and drink, places for eating or drinking, etc.)

2.5.1 (m) foreign language (level of own speaking ability and understanding, correctness, etc.) 
weather (climate, weather conditions, seasons, etc.) (cf. Van Ek, 1976:27-35).

When working according to this list, one still has to decide which aspects of life in the target country one wants to include in a course. Obviously, supplying the full spectrum of aspects that could be included under the 14 topics is impossible, and a selection has to be made. When writing a foreign language course, special consideration should be given to aspects of the particular "system of rules, principles, and schemes of social interaction" (Bierwisch, 1980:7) of the foreign country. For the purpose of the equations he uses to define communicative processes, Bierwisch calls this system of rules, principles, and schemes of social interaction the $S I$, "according to which the interactional setting ias of $m a$ [= meaningful activity] is construed and its communicative sense is determined" (1980:7).

Bierwisch points out the different types of issues at stake here: "there are on the one hand certain general principles like those of rational cooperation, obeying obligations, acknowledging motivations, needs, and interests, etc. On the other hand, there are various forms of conventional, more or less institutionalized rules and structures" (1980:7) that can vary considerably from place to place. The German word Landeskunde is an appropriate term to use in this context. Authors of suggestopedic texts should include relevant information about the Landeskunde of the target culture, especially about the aspects that could cause confusion in the novice. As Bierwisch points out, the conventions and signs that one has to understand in a new culture (in his terminology the ma or "meaningful activities") may be "a gesture, a particular type of dressing, a specifically placed stone, or what not" (1980:6). It is essential that the course and, as far as possible the text itself, should contain enough information about the conditions in the countries where the target language is spoken to enable the learners to communicate effectively and "to facilitate substantial discussion on an inter cultural level in class" (Kussler and Bodenstein, 1985:13).

\subsubsection{Step two:}

Identify the language functions or speech acts that will be required in the communicative situations the learners are likely to be exposed to (within the context of the topic areas mentioned above).

In order "to survive (linguistically speaking) in temporary contact with foreign language speakers in everyday situations, whether as visitor to the foreign country or with visitors to their own country", and "to establish and maintain social contacts" (Van Ek, 1976:24-5), learners will have to be able to fulfil the following language functions or speech acts :

2.5.2 (a) Imparting and seeking factual information (identifying, reporting, correcting, asking, etc.);

2.5.2 (b) Expressing and finding out intellectual attitudes (expressing agreement or disagreement, accepting or declining an offer or an invitation, etc.);

2.5.2 (c) Expressing and finding out emotional attitudes (expressing pleasure or 
displeasure, inquiring about pleasure or displeasure, expressing hope, surprise, disappointment, worry, fear, sympathy, gratitude, etc.);

2.5.2 (d) Expressing and finding out moral attitudes (apologizing, expressing approval or disapproval, appreciation, regret or indifference, etc.);

2.5.2 (e) Getting things done (suasion) (suggesting a course of action, requesting, inviting, advising or directing others to do something, offering or requesting assistance, etc.);

2.5.2 (f) Socializing (attracting attention, greeting people, congratulating people, etc.) (cf. Van Ek, 1976:37-39).

\subsubsection{Step three:}

Establish a hierarchy of importance in both categories: topic areas as well as speech acts.

This step can be seen as a fine-tuning of steps one and two. Once the priority of the elements that should be incorporated in a course has been determined, the frame for a meaningful progression for the text (as well as for the course) becomes apparent.

When steps one, two and three have been accomplished, the basis for one's text has been established. What one now has to do, is write a dramatic story that incorporates the situations likely to occur within the given topic areas and the speech acts or language functions which will be called for in such situations. Of course the language forms used to fulfil the language functions, the so-called "exponents" (Van Ek, 1976:15), can only be a sample of what learners could expect in the real-life situation. "It is obviously impossible, at this level, to prepare the learner for the full range of language he may be confronted with, but it should be attempted to prepare him at least for what he is most likely to be confronted with" (Van Ek, 1976:16). The language for the text should, therefore, be selected carefully to ensure a representative sample so that the text can serve as a linguistic "survival kit". Thus the story should be presented as a natural, authentic dialogue, with priority given to the aspects most important to the individual target group.

At this stage, all that remains to be done before one can start writing the story, is to decide on appropriate characters, an interesting plot and a suitable setting in terms of location and time.

Incidentally, the formal procedure of identifying the topic areas and speech acts usually helps generate creative ideas for the plot of the text. In her account of how adolescents can learn through narrative, Wanner points out that, paradoxically, a formalized, ready-made structure can be particularly effective in liberating writers to discover and explore their own ideas (1994:6566). Furthermore, in analysing the difference between speaking and writing, Elbow indicates that too much "thinking about" what one writes and too much "editing" of what one has written can be a problem: "writing has the advantage of permitting more editing. But that's its downfall too. Almost everybody interposes a massive and complicated series of editings between the time words start to be born into consciousness and when they finally come off the end of the pencil or typewriter onto the page" (Elbow, 1973:5). Elbow goes on to explain that "editing, in itself, is not 
he problem. Editing is usually necessary if we want to end up with something satisfactory. The oroblem is that editing goes on at the same time as producing" (1973:5). My experience has been hat the strict and formalized structure (provided by the topics and speech acts selected) draws attention away from the "editor", who is, according to Elbow, "constantly looking over the houlder of the producer and constantly fiddling with what he's doing while he's in the middle of rying to do it" (1973:5).

Another strategy is to keep in mind the more philosophical and general requirements of Suggestopedia, as mentioned under point 2.1 to 2.5 . This helps one to decide what elements to nclude in order to create an appropriate emotional tone for the text.

Lastly, keeping in mind the balance proposed by Kussler and Bodenstein between familiarity and isense of the unknown, may further simplify the process of generating ideas and writing suitable exts for foreign language courses (1985:14). Kussler and Bodenstein point out that a fair degree of "familiarity with phenomena" will lead to identification on behalf of the reader (student), while "a certain strangeness, a sense of the unknown" will create the interest and curiosity equired (1985:14). This means that the characters should be recognisable by the students as people whom one could meet in real life, who have dreams and aspirations that one can anderstand and who experience universally human situations that one could identify with. The setting, however, in which these characters experience the universally human situations should deally appear exotic to the students, socially as well as geographically, in order to introduce the earners to real life conditions one could expect in the countries where the target language is poken (cf. 2.5.1 for more detailed treatment).

Experience has shown that writing suggestopedic texts according to the principles and guidelines lescribed, is in fact not nearly as difficult as it may seem, not even for novices, and I sincerely tope that this contribution may serve as an incentive for many new "script writers" to discover heir (dormant) talents.

\section{ART THREE}

n the following section, examples from a German and a Zulu text written at the University of itellenbosch will be examined. Both texts were written in accordance with the didactic and tructural principles discussed above. The first part of the introductory scenes of first the German nd then the Zulu text will be analysed in order to show how the proposed guidelines were put nto practice.

$\mathrm{n}$ both cases the following format is used to illustrate the underlying principle:

irst, a summary of the plot of the first part of the scene is given. Then the exponents (language orms) are quoted, and the topic areas and speech acts pertaining to each part of the dialogue dentified. 
In both cases the plot consists of a love story, in many ways reminiscent of a typical television soap opera. Students can easily recognise the underlying situation of falling in love and should normally be able to identify, to a varying degree, with the characters emotionally. The relationship between male and female protagonists is the Leitmotiv in both texts, but this Leitmotiv is always accompanied by "various other themes, e.g. the background and interests of the characters, activities alone or together, and, mainly, the steady narrative line" (Kussler and Bodenstein, 1985:15).

The geographical settings of the two texts, which, according to the scheme mentioned above, should emphasise the unfamiliar and the exotic, differ considerably. Whereas the German text takes South African students away from home into another country (Germany), the Zulu text is situated in South Africa, in Johannesburg. As such the geographical setting is familiar to most of the students. The exotic elements in the Zulu text predominantly lie in the social setting, so that non-African students are introduced to and develop a sensitivity for customs and forms of social interaction that may differ considerably from their own. One of the main goals of the Zulu-course is to replace the perception prevalent in many non-African South Africans that African languages are, linguistically and socially, inferior to other (e.g. European languages) and "not suitable for functions such as further education, science, technology, business, law and government" (Luckett 1995:74).

Note should be taken of the special didactic function of the translation in suggestopedic texts. Its main function is to enable students to compare the words and expressions in the target language with those in their own language as precisely as possible. For this reason a rather contrived translation is often used in suggestopedic courses, especially in cases where the target language and the mother tongue of the students have a very disissimilar syntax.

\subsection{German course:}

"Eine Oper für die Tupari"

(Ruth Bodenstein and Rainer Kussler)

\section{"An Opera for the Tupari"}

\subsubsection{Plot:}

The main characters, Werner von Übermut and Roswitha Singvogel, meet aboard a Lufthansa Jumbo. They are flying home to Germany after spending some time working in Brazil: Roswitha as a music teacher and Werner as a freelance journalist. The two get along like a house on fire. Werner is a fan of Hermann Hesse, the author of the novel Roswitha was reading when Werner introduced himself, and they establish another common interest: music. Soon Werner starts telling Roswitha about the dream of his life. He wants to build an opera house for an indigenous people in the Amazon jungle, the Tupari. Roswitha is amazed and impressed, but whenever the topic is raised, in this scene and the following ones, she has a few questions to ask about this (far-fetched?) idea... 
3.1.2 Exponents, together with the topic areas ( $t a$ ) and speech acts (sa) they refer to:

\section{Erster Akt, 1. Szene:}

In einem Lufthansa-Jumbo, unterwegs von Rio de Janeiro nach Frankfurt am Main. Durch das Fenster sieht man die Sonne: rosa und golden steht sie am Horizont.

Werner von Übermut hat lange aus dem Fenster geguckt.

Plötzlich erkennt er das Buch, das seine Nachbarin liest.

\section{"In einem Lufthansa-Jumbo"}

In a Lufthansa Jumbo, en route from Rio de Janeiro to Frankfurt on the Main (river). Through the window one can see the sun: pink and golden (she is standing) on the horizon. W. von Ü. has for a long time been looking through the window. Suddenly he recognises the book which his neighbour is reading.

$t a$ : travel, foreign places, means of travel: aviation activities during flight, passing the time nature, geographical phenomena cultural habits: reading, literature relations with people: interest, making contact

sa: $\quad$ none $^{3}$

\section{Werner:}

Entschuldigen Sie bitte, ich sehe, Sie lesen Hermann Hesse?
Please excuse me, I see (that) you are reading $H$. Hesse?

$s a$ : socializing: attracting attention identifying something as a fact (asking something in a rhetorical way)

Roswitha:

Ja. Ach, Sie sprechen auch deutsch?

Yes. Oh, you speak German too?
ta: personal identity: home language
sa: expressing agreement
expressing surprise
identifying something as a fact

\section{Werner:}

Ja. Ich bin Deutscher.

Yes. I am German.

ta: personal identity: nationality

sa: $\quad$ imparting information

Aber ich lebe in Brasilien.

But I am living in Brazil.

$t a$ : personal identity: present dwelling place

places, foreign countries 
sa: imparting information

Roswitha:

Ach, Sie auch?

sa: $\quad$ expressing surprise

What, you too?

Ich wohne nämlich auch dort.

I happen to live there as well.

In Belo Horizonte.

In Belo Horizonte.

ta: personal identity: present dwelling place places, foreign countries, cities of the world

sa: imparting information

qualifying what has been said previously

Werner:

Das kenne ich.

sa: imparting information

I know that (place).

expressing knowledge of something

Dort leben viele Deutsche.

$s a$ : imparting information

Many Germans live there.

Übrigens,

ich heiße Übermut.

By the way,

Werner von Übermut.

my name is Übermut.

$t a$ : personal identity: name, surname

$s a$ : socializing: introducing yourself

Roswitha (lächelt):

(smiles)

Übermut? Wirklich?

Übermut? Really?

sa: $\quad$ expressing surprise, disbelief

asking for confirmation

Werner (lacht auch):

(also laughs)

Ja. Und das stimmt auch.

Yes. And it is quite true.

$s a$ : confirming what one has said before imparting information

Ich bin oft ziemlich übermütig.

I am rather exuberant sometimes.

$t a$ : personal identity: personality, character

$s a$ : imparting (additional) information identifying something as a fact

Aber nennen Sie mich doch bitte

But please call me 
Werner.

Werner.

ta: personal identity: name, surname

sa: socializing: introducing yourself

suasion: suggesting, requesting a course of action

Roswitha:

Gern.

sa: $\quad$ accepting a suggestion

With pleasure.

Und ich bin Roswitha.

And I am Roswitha.

Roswitha Singvogel.

Roswitha Singvogel.

ta: personal identity: name, surname

sa: socializing: introducing yourself

(End of sample of the German course)

\subsection{Zulu course:}

The goal of this course is not primarily to teach the learners to communicate in Zulu - the course is too short for this formidable task. Rather, it sets out to generate appreciation for the Zulu language and understanding of the Zulu culture and "Weltanschauung", especially of "Ubuntu", the so-called "African Humanism".

In order to understand the reason behind the unidiomatic and somewhat contrived translation, special note should be taken of the function of translation in suggestopedic texts (cf. footnote 4).

"Uthando emoyeni" (John Moyana and Ruth Bodenstein)

\subsubsection{Plot:}

Sipho, a businessman, wants to travel from Johannesburg to Durban. He approaches Thoko Zondi, a ground hostess working at the counter of the South African Airways' reservation office, to book his seat. As he explains where he wants to go and who he is, Thoko becomes aware of the fact that Sipho is showing more than the normal interest in her as a woman. It is clear that the two are attracted to each other. By lucky chance, Sipho chooses exactly the same flight to Durban on which Thoko is booked - to fly to Durban for her vacation. This coincidence ensures that the two will later meet again on board the aeroplane. 
3.2.2 Exponents, together with the topic areas ( $t a)$ and speech acts (sa) they refer to:

"Uthando emoyeni"

Isiqhephu sokuqala:

\section{S.A.A. Reservation Office}

Ngolwesibili ekuseni.

u Sipho, usomabizinisi, ungena emnyango.

ta: travel, travel arrangements services at the airport professions
"Love in the air"

Act 1:
Tuesday morning.

Sipho, a businessman,

walks in through [at] the door.

Sipho: Uxolo nkosazana,

Excuse me, madam, nqicela usizo.

would you please help me?

[I am asking you to help me]

sa: socializing: attracting attention requesting others to do something requesting assistance

Information hostess:

Yebo baba, ngingakusiza. Yes, sir, I can help you.

Sawubona. Good day.

$s a$ : expressing willingness / ability to assist offering assistance when meeting people: greeting

Sipho: Yebo sawubona.

$s a$ : when meeting people: greeting

Hostess:

Unjani? How are you?

$s a$ : inquiring about other people's well-being

Sipho:

Nqisaphila.

Wena usaphila?

I am well.

And how are you?

$s a$ : expressing own well-being

[You are also well?]

inquiring about other people's well-being 
Hostess:

Yebo, ngisaphila.

Yes, I am also well.

sa: expressing own well-being

Ngingakusiza ngani?

How can I help you?

ta: $\quad$ services

[With what can I help you?]

$s a$ : expressing willingness / ability to assist

offering assistance

\section{Sipho:}

Bengifuna ukuya eThekwini ngendiza ngolwesihlanu.

Ingabe

indawo ngingayithola?

ta: travel, itinerary

I would like to go to Durban

on Friday.

[on board on the fifth day]

I wonder [may I know]

whether I can get a seat?

[a place I can find]

sa: expressing a wish, preference, intention, plan inquiring whether something is possible requesting others to do something

Hostess:

Yebo.

Yes.

Kayikho inkinga kulokho.

No problem.

[not is a problem in that]

sa: confirming that something is possible reassuring someone not to be concerned

Ingabe ubaba ngubani?

What is your name?

ta: personal identification: name, surname

[may I know - your name - who is it?]

$s a$ : enquiring about someone's name

Sipho:

Mina ngingu Sipho Mzimela. I am Sipho Mzimela.

[me, I am called Sipho M.]

sa: identifying yourself, stating your name

\section{Hostess:}

Ngiyabonga Mnumzana Mzimela.

Thank you, Mr. Mzimela.

Mina ngingu Nkosazana

I am Miss Thoko Zondi.

Thoko Zondi.

sa: socializing: when meeting people

[me, I am called Thoko Z.] 
thanking someone for information

identifying yourself, stating your name

(End of sample of Zulu text)

\section{CONCLUSION}

Although the guidelines for writing texts presented in this paper pertain to foreign language teaching in a suggestopedic setting, many of them can be understood in a broader sense to include second language teaching in suggestopedic courses as well as foreign and/or second language teaching according to communicative approaches other than suggestopedia. Teachers not using the suggestopedic approach may have to adapt the guidelines, but they should generally have little trouble translating the fundamental principles and modifying the essence of the strategies provided in order to generate creative new models for their own teaching environments.

\section{NOTES}

1 The new German textbook for beginners, "Die Suche" (1995), is a particularly clear example. It uses one continuous text as basis throughout all lessons. Although there are important differences between this text (written by a famous German author, Hans Magnus Enzensberger) and the typical suggestopedic text, the mere fact that a single text has been used indicates the influence of Suggestopedia. One of the authors has admitted this in conversation, but no official reference to any such influence has been made so far.

${ }^{2}$ The use of these three steps in writing suggestopedic texts was also presented in the form of a round table: "Writing suggestopedic texts - the South African way", at the "Conference of the International Alliance for Learning" at San Antonio, Texas, January 1997.

${ }^{3}$ Although the speech acts "imparting information", "identifying something" or "reporting on something", could be identified in this section, the speech acts "proper", i.e. those which the learners are required to master, only commence with the dialogue. 


\section{REFERENCES}

BIERWISCH, M. 1980. Semantic structure and illocutionary force. In Searle, JR. (Ed), Speech act theory and pragmatics. Dordrecht, The Netherlands: D. Reidel Publishing Company.

BLAIR, RW. 1985. Stories and story telling in first-level language learning: a re-evaluation. Per Linguam, 1(2):25-33.

BODENSTEIN, RH AND HR KUSSLER. 1984. Eine Oper für die Tupari. Unpublished suggestopedic text for a beginners' course in German, University of Stellenbosch.

BOTHA, H Ludolph. 1990. Suggestopaedia in theory and practice. Per Linguam, Special Issue No.4.

DHORITY, LF. 1984. Acquisition through creative teaching (ACT): The artful use of suggestion in foreign language instruction. Sharon, Mass.: Center for Continuing Development.

DRYDEN, G AND J VOS. 1994. The learning revolution. Aylesbury, UK: Accelerated Learning Systems.

ELBOW, P. 1973. Writing without teachers. Oxford: Oxford University Press.

EISMAN, V, HM ENZENSBERGER, K VAN EUNEN, B HELMLING, B KAST, I MUMMERT AND M THURMAIR. 1995. Die Suche. Das andere Lehrwerk für Deutsch als Fremdsprache. Berlin: Langenscheidt.

GOLEMAN, D. 1996. Emotional intelligence. Why it can matter more than IQ. London: Bloomsbury.

FRIEDRICH, G. 1994. Suggestive Lehr- und Lernverfahren unter neurodidaktischen Gesichtspunkten. Kritische Anmerkungen zu "Suggestopädie" bzw. "Superlearning". Pädagogische Welt 48(2):77-80.

KRAG, W. 1989. Zur Wirkung der suggestopädischen Lehrmethode: Allgemeine theoretische Begründung und empirische Überprüfung. Frankfurt a.M.: Peter Lang.

KUSSLER, HR AND RH BODENSTEIN. 1985. Suggestopedic texts for foreign language teaching: some literary and didactic considerations. Per Linguam, 1(1):11-20.

KRASHEN, SD AND TD TERRELL. 1983. The natural approach. Language acquisition in the classroom. Oxford: Pergamon Press. 
KRASHEN, SD. 1985. The input hypothesis: issues and implications. New York: Longman.

LOZANOV, G. 1982. Suggestology and suggestopedia. In R.W. Blair (Editor), Innovative approaches to language teaching. Rowley, Ma.: Newbury House Publishers.

LUCKETT, K. 1995. National additive bilingualism: towards a language plan for South African education. In K. Heugh, A. Siegrühn \& P. Plüddemann (Eds), Multilingual Education for South Africa. Isando, South Africa: Heinemann.

MANS, EJ. 1981. "Joyful and easy language learning" oder von der Reservekapazität der Fremdsprachendidaktik. Bemerkungen zu G. Lozanovs "Suggestology and Outlines of Suggestopedy". EAST, 2/81: 258-266.

MOYANA, J AND RH BODENSTEIN. 1994. Uthando emoyeni. Unpublished suggestopedic text for a Zulu language appreciation course of the South African Airways, University of Stellenbosch.

RICHARDS, JC AND TS RODGERS. 1986. Approaches and methods in language teaching. Cambridge University Press.

ROSE, C. 1985. Accelerated Learning. Aylesbury, Great Britain: Accelerated Learning Systems.

SCOVEL, T. 1979. Suggestology and outlines of Suggestopedy. Georgi Lozanov. Review. TESOL Quarterly, 13(2):255-266.

SYLWESTER, R. 1995. A celebration of neurons. An educator's guide to the human brain. Alexandria, VA: Association for Supervision and Curriculum Development.

VAN EK, JA. 1976. The Threshold Level for modern language learning in schools. Groningen, The Netherlands: Longman.

VIELAU, A. 1988. Voll im Trend? - Kritische Anmerkungen. Zielsprache Englisch 4/88:16-20.

WANNER, SY. 1994. On with the story. Adolescents learning through narrative. Portsmouth, NH: Boynton/Cook. 